Biogeosciences Discuss., https://doi.org/10.5194/bg-2018-195

Manuscript under review for journal Biogeosciences

Discussion started: 3 May 2018

(c) Author(s) 2018. CC BY 4.0 License.

(c) (1)

\title{
1 Seasonal and spatial variability of methane emissions \\ 2 from a subtropical reservoir in Eastern China
}

3

4

5

6

7

8

\author{
Yang Le*, Li Hepeng, Yue Chunlei, Wang Jun \\ Zhejiang Academy of Forestry, Hangzhou, 310023, China \\ Corresponding author: *E-mail: yangboshi@live.cn
}


Biogeosciences Discuss., https://doi.org/10.5194/bg-2018-195

Manuscript under review for journal Biogeosciences

Discussion started: 3 May 2018

(c) Author(s) 2018. CC BY 4.0 License.

\section{Abstract:}

10 Subtropical reservoirs are important source of atmospheric methane $\left(\mathrm{CH}_{4}\right)$. This study

11 aims to investigate the spatiotemporal variability of $\mathrm{CH}_{4}$ emission, using the methods

12 of static floating chambers and bubble traps, from the water surfaces of Xin'anjiang

13 Reservoir. Seasonal variability showed that $\mathrm{CH}_{4}$ emission from the main reservoir

14 body was high in autumn and low in spring, with medium values in summer and

15 winter. The dynamics of $\mathrm{CH}_{4}$ emission was flat from February to June, but fluctuated

16 dramatically from July to January in the upstream river, which was interrupted by the

17 bubbles in the second half year. However, $\mathrm{CH}_{4}$ emission was largely influenced by the

18 streamflow in the downstream river, with a minimum value in February due to an

19 extreme low streamflow $\left(275 \mathrm{~m}^{3} \mathrm{~s}^{-1}\right)$. Spatial variability showed the upstream river

20 had the highest $\mathrm{CH}_{4}$ flux $\left(3.90 \pm 7.80 \mathrm{mg} \mathrm{CH} \cdot \mathrm{m}^{-2} \cdot \mathrm{h}^{-1}\right)$, followed by the downstream

21 river $\left(0.50 \pm 0.41 \mathrm{mg} \mathrm{CH} \cdot \mathrm{m}^{-2} \cdot \mathrm{h}^{-1}\right)$, and the main reservoir body stood the last place

$22\left(0.01 \pm 0.07 \mathrm{mg} \mathrm{CH}{ }_{4} \cdot \mathrm{m}^{-2} \cdot \mathrm{h}^{-1}\right)$. Therefore, it was necessary to capture the variation of

$23 \mathrm{CH}_{4}$ emission from reservoirs in the space and time scales to avoid the error of

24 estimating the $\mathrm{CH}_{4}$ emission incorrectly.

25

26 Key words: Spatiotemporal variability; $\mathrm{CH}_{4}$ flux; $\mathrm{CH}_{4}$ emission; Bubble; Xin'anjiang

27 Reservoir. 
Biogeosciences Discuss., https://doi.org/10.5194/bg-2018-195

Manuscript under review for journal Biogeosciences

Discussion started: 3 May 2018

(c) Author(s) 2018. CC BY 4.0 License.

\section{Introduction}

Reservoirs are an important type of wetland, which used to be often regarded as clean energy. However, the view was denied by a growing body of researches documenting their role as carbon sources. Deemer et al. (2016) showed that $\mathrm{CH}_{4}$ emissions are responsible for the majority of the radiative forcing from reservoir water surfaces (approximately $80 \%$ over the 100 -year timescale). The greenhouse gas emission data was limited to 36 Asian reservoirs, among which $\mathrm{CH}_{4}$ emission flux data was available in 3 reservoirs in China, i.e., Three Gorges (Yang et al., 2013; Zhao et al., 2013), Ertan (Zheng et al., 2011), Miyun (Yang et al., 2014). Actually, China had 98,002 dams of different sizes with 142 large-size hydroelectric reservoirs, which did not include the dams under construction or planed now. Thus, more hydroelectric reservoirs distributed in the different geographical regions and climate zones in China should be selected to measure $\mathrm{CH}_{4}$ emission flux to explore the rules of $\mathrm{CH}_{4}$ emission from hydroelectric reservoirs.

Diffusive flux, gas bubble flux, and aquatic vegetation are main pathways for $\mathrm{CH}_{4}$ emission from open water areas in reservoirs (Bastviken et al., 2011). Plant-medium transport is an important $\mathrm{CH}_{4}$ emission pathway in reservoir area with abundant vegetation cover (Bastviken et al., 2011). However, in the no vegetation-distributed areas, ebullition was a dominant way for $\mathrm{CH}_{4}$ emission, while molecular diffusion was a secondary way for $\mathrm{CH}_{4}$ emission from the reservoir water surfaces, although ebullition was found to be episodic (Maeck et al., 2014), because the ebullitive $\mathrm{CH}_{4}$ flux was larger by $1 \sim 3$ orders of magnitude than the diffusive $\mathrm{CH}_{4}$ flux (Delsontro et al., 2010, 2011). High ebullitive $\mathrm{CH}_{4}$ flux was often observed in the shallow zones, river deltas, and inflow rivers (Delsontro et al., 2010, 2011, 2016), which was influenced by allochthonous organic carbon input and burial (Sobek et al., 2012). Chamber methods were used to measure the $\mathrm{CH}_{4}$ emission flux in the previous studies located in the 3 reservoirs in China, and chamber methods measured the total $\mathrm{CH}_{4}$ emission flux (diffusion plus ebullition) across water-air interface (Yang et al., 2013, 2014; Zheng et al., 2011; Zhao et al., 2013). Probably these previous studies didn't 
Biogeosciences Discuss., https://doi.org/10.5194/bg-2018-195

Manuscript under review for journal Biogeosciences

Discussion started: 3 May 2018

(c) Author(s) 2018. CC BY 4.0 License.

show the bubble $\mathrm{CH}_{4}$ flux magnitude.

Spatial and temporal variability in $\mathrm{CH}_{4}$ emission are often reported in the reservoirs (Yang et al., 2013; Zhao et al., 2013; Zheng et al., 2011; Muzenze et al., 2014). The spatial variability in $\mathrm{CH}_{4}$ emission from reservoirs are caused by the impoundment of the dams, which changed the hydrological characteristics of the original river. Upstream and downstream of the dams, outlet of the dam, and inflow rivers to the reservoirs had distinct $\mathrm{CH}_{4}$ emission levels in a whole reservoir's system (Muzenze et al., 2014; Kemenes et al., 2007; Abril et al., 2005), because of the hydrological variables (e.g., water velocity, water depth) (Yang et al., 2013) and dam operation strategy (Fearnside and Pueyo, 2012). Turning to the temporal variability in $\mathrm{CH}_{4}$ emission, temperature, water column mixing, dissolved oxygen (DO) concentration and other environmental variables (e.g., retention time, benthic metabolism) controlled the temporal variability in $\mathrm{CH}_{4}$ emission (Yang et al., 2013; Natchimuthu et al., 2016; Rodriguez and Casper, 2018). For example, $\mathrm{CH}_{4}$ emission reached the maximum in the summer and turned to the low levels in the other seasons in the Three Gorges Reservoir, which was regulated by temperature, DO, and water velocity (Yang et al., 2013). Temperature regulated the temporal variability of $\mathrm{CH}_{4}$ emission in the 3 lakes (Följesjön, Erssjön, Skottenesjön) of southwest Sweden (Natchimuthu et al., 2016). Due to the differences in hydrology, water quality, meteorological, and biological variables, the spatiotemporal variability in $\mathrm{CH}_{4}$ emission should be explored in the reservoirs, which could understand the differences of $\mathrm{CH}_{4}$ emission in time and space scales.

Downstream rivers also cannot be ignored because of the degassing fluxes at the turbines or spillways and high fluxes in the downstream watercourses. Downstream emission accounted for $50 \%$ of total $\mathrm{CH}_{4}$ emissions from the Balbina Reservoir in Brazil (Kemenes et al., 2007), roughly $30 \%$ of total greenhouse gas emissions for the 8 reservoirs in the dry tropical biomes region in Brazil (Ometto et al., 2013), and 10\% of total $\mathrm{CH}_{4}$ emission for Nam Theum 2 Reservoir in Laos (Deshmukh et al., 2016). 
Biogeosciences Discuss., https://doi.org/10.5194/bg-2018-195

Manuscript under review for journal Biogeosciences

Discussion started: 3 May 2018

(c) Author(s) 2018. CC BY 4.0 License.

Therefore, $\mathrm{CH}_{4}$ emission from the downstream river should be included in a hydroelectric reservoir.

Two hypothesis are postulated here: (1) the temporal variations in $\mathrm{CH}_{4}$ emission from water surface are influenced by the temperature, thus a high $\mathrm{CH}_{4}$ emission flux would be observed in summer and relative low $\mathrm{CH}_{4}$ emission fluxes occurred in other seasons; (2) upstream and downstream rivers have a great $\mathrm{CH}_{4}$ emission because of the fast water flow and the low water depth there. The specific objectives in this study are to investigate the temporal variations in $\mathrm{CH}_{4}$ emission from Xin'anjiang Reservoir, and upstream and downstream sites are contrasted with those in the reservoir to show the spatial variations in $\mathrm{CH}_{4}$ emission from the reservoir.

\section{Materials and Methods}

\subsection{Study sites}

Figure 1. Dynamics of precipitation, evaporation, air temperature, and water level in the Xin'anjiang Reservoir region

Xin'anjiang Reservoir $\left(29^{\circ} 28^{\prime}-29^{\circ} 58^{\prime} \mathrm{N}, 118^{\circ} 42^{\prime}-118^{\circ} 59^{\prime} \mathrm{E}\right)$ is located in the north subtropical zone, with the mean air temperature of $17.7^{\circ} \mathrm{C}$, the total precipitation of $2015.1 \mathrm{~mm}$, and the total evaporation of $712.9 \mathrm{~mm}$ (Figure 1). Xin'anjiang Reservoir was built in 1959, which has a water area of $567 \mathrm{~km}^{2}$, a mean depth of $34 \mathrm{~m}$. The water storage of the reservoir is about $1.78 \times 10^{10} \mathrm{~m}^{3}$, the yearly average inflow and the outflow discharge are $9.4 \times 10^{9} \mathrm{~m}^{3}$ and $9.1 \times 10^{9} \mathrm{~m}^{3}$, respectively, and the water retention time is about 2 years ( $\mathrm{Li}$ et al., 2011). Water level fluctuated between $98 \mathrm{~m}$ to $104 \mathrm{~m}$ in Xin'anjiang Reservoir in 2015 (Figure 1). The Xin'anjiang Reservoir is dendritic shape, which consists of northwest lake, northeast lake, southwest lake, southeast lake, and central lake (Figure 2). Among the 5 sub-lakes, the watercourse of northwest lake is the most dominant upstream inflow river, which occupy $60 \sim 80 \%$ of total surface runoff. Thus, the northwest lake is regarded as the main upstream river of the Xin'anjiang Reservoir, and the reservoir's main body consisted of northeast lake, 
Biogeosciences Discuss., https://doi.org/10.5194/bg-2018-195

Manuscript under review for journal Biogeosciences

Discussion started: 3 May 2018

(c) Author(s) 2018. CC BY 4.0 License.

southwest lake, southeast lake, and central lake, and the downstream river is the watercourse below the Xin'anjiang Dam.

Figure 2. The distribution of the sampling transects and sampling sites in the Xin'anjiang Reservoir

The sampling campaign was conducted in the 4 sub-lakes and the downstream river (Figure 2). The northwest (NW) lake transect (294'03" N, 118 43'04” E) was located in Jiekou town of Anhui Province, where was the main inflow inlet of Xin'anjiang Reservoir and had a width of $0.3 \mathrm{~km} .3$ sampling points (NWP1, NWP2, NWP3) were chosen from the margin to pelagic zones in the NW transect. The northeast (NE) lake transect (29038'44'N, 11903'03'E) was located in open water areas of the NE lake near the outlet of a tributary (Jinxianxi). The southwest (SW) lake transect $\left(29^{\circ} 28^{\prime} 18^{\prime \prime} \mathrm{N}, 18^{\circ} 44^{\prime} 39^{\prime \prime} \mathrm{E}\right)$ was located in the open water areas near Maotoujian Island, where was outlet of the Jiangjia tributary and Fengkou tributary. The southeast lake (SE) transect $\left(29^{\circ} 28^{\prime} 39^{\prime} \mathrm{N}, 118^{\circ} 45^{\prime} 20^{\prime \prime} \mathrm{E}\right)$ was located in the open water areas between Guihua Island and Mishan Island, where was about $5 \mathrm{~km}$ upstream of the Xin'anjiang Dam. 5 sampling points (from P1 to P5) were chosen from the margin to pelagic zones in the NE, SW, and SE transects, respectively. In addition, 4 sampling points were selected in the downstream river below the dam, with a distance of $0.35 \mathrm{~km}, 1 \mathrm{~km}, 4 \mathrm{~km}$, and $7 \mathrm{~km}$ away from the Xin'anjiang Dam, respectively, which was named as DRP1, DRP2, DRP3, and DRP4, respectively.

\section{2. $\mathrm{CH}_{4}$ flux measurements}

In this study, the floating static chambers were used to collect $\mathrm{CH}_{4}$ gas samples from the surface of Xin'anjiang Reservoir from December 2014 to December 2015. Monthly measurement was carried out for each sampling site in the morning, and the measurement lasted for half an hour for each point. The bubble traps were used to collect the bubbles in the upstream river from August 2016 to November 2017. The bubbles were collected once or twice in the NW transect every month except November, 2016, January and February, 2017, and the collection campaign often 
Biogeosciences Discuss., https://doi.org/10.5194/bg-2018-195

Manuscript under review for journal Biogeosciences

Discussion started: 3 May 2018

(c) Author(s) 2018. CC BY 4.0 License.

The diffusive $\mathrm{CH}_{4}$ emission flux was measured using the static chamber and gas chromatograph method. The floating static chamber $\left(0.29 \mathrm{~m}^{2}\right.$ for the basal area; 0.117 $\mathrm{m}^{3}$ for the volume) consisted of a plastic box without a cover that was wrapped in light-reflecting and heatproof materials to prevent temperature variation inside the chambers; in addition, plastic foam collars were fixed onto opposite sides of the chamber. The headspace height inside the chamber was about $35 \mathrm{~cm}$. A silicone tube (0.6 $\mathrm{cm}$ and $0.4 \mathrm{~cm}$ outer and inner diameters, respectively) was inserted into the upper central side of the chamber to collect gas samples, and the gas samples were dried with plexiglass tubes filled with Calcium chloride anhydrous (analytical reagent), which could remove the moisture in the gas samples and prevent the biological reactions. Another silicone tube was inserted into the upper corner side of the chamber to keep the air pressure balanced between the inside and the outside of the chamber. All measurements were performed in triplicate. The gases in the headspace of the chamber were collected into air-sampling bags $(0.5 \mathrm{~L}$; Hedetech, Dalian, China) four times every $7 \mathrm{~min}$ over a $21 \mathrm{~min}$ period using a hand-driven pump (NMP830KNDC; KNF Group, Freiburg, German) (Yang et al., 2013). Once the gas was collected from the chambers, the gas samples were stored in the air-sampling bags until analysis in the laboratory. The air-sampling bags made of aluminum can store the gas samples for 7 days, which does not absorb and react with $\mathrm{CH}_{4}$. The leakage and memory effects of air-sampling bags have been tested before our experiments.

The bubble trap consisted of an inverted $30 \mathrm{~cm}$ diameter circular funnel fixed with a closed plastic bottle (volume: $0.56 \mathrm{~L}$ ) in its narrow neck, and an additional skirt (50 $\mathrm{cm}$ diameter circular) was fixed in the large mouth of the funnel to enlarge the bubble collection range (Wik et al., 2013). Each funnel was stabilized by three equally sized weights to make sure no tiny bubbles left in the bottles at initial stage. 16 to 26 bubble 
Biogeosciences Discuss., https://doi.org/10.5194/bg-2018-195

Manuscript under review for journal Biogeosciences

Discussion started: 3 May 2018

(c) Author(s) 2018. CC BY 4.0 License.

two neighbouring bubble traps when the bubbles were sampled. The trapped gas bubbles would drain the water from the bottles after about 20-40 hours placement. The left water in the bottles was measured by a graduate to calculate the volume of trapped gas bubbles. The trapped gas was diluted 1000 times by injecting $1 \mathrm{~mL}$ trapped gas into $1 \mathrm{~L}$ or $0.5 \mathrm{~L}$ previously $\mathrm{N}_{2}$-filled gas bags, because the $\mathrm{CH}_{4}$ concentration of the trapped gas was too high for the gas chromatograph to reach.

The air-sampling bags were analyzed within 3 days using a gas chromatograph (Agilent 7890A; Agilent Technologies, Santa Clara, USA) equipped with a flame ionization detector (FID) and separated with a Teflon column $(3 \mathrm{~m} \times 3 \mathrm{~mm})$ packed with Porpak-Q column (80-100 mesh). The oven, injector, and detector temperatures were at $70{ }^{\circ} \mathrm{C}, 25{ }^{\circ} \mathrm{C}$, and $200{ }^{\circ} \mathrm{C}$, respectively. The flow rate of the carrier gas $\left(\mathrm{N}_{2}\right)$ was $25 \mathrm{~mL} \cdot \mathrm{min}^{-1}$, and the flow rate of $\mathrm{H}_{2}$ and the compressed air was set to 40 and 30 $\mathrm{mL} \cdot \mathrm{min}^{-1}$, respectively. Standard mixed gas $\left(\mathrm{CH}_{4}: 1.83 \mathrm{ppm}\right.$; provided by China National Research Center for Certified Reference Materials, Beijing) was used to quantified the $\mathrm{CH}_{4}$ concentration in one of every 10 samples, which kept the coefficient of variation of the $\mathrm{CH}_{4}$ concentration in the replicated samples below $1 \%$.

The increasing rate of the gas concentration $(\mathrm{d} c / \mathrm{d} t)$ within the static chamber was calculated as the slope of the linear regression of the gas concentration versus time. It was suggested that the nonlinear relation between gas flux and time would be better to determine the steeper initial slope in the chambers. If one plots the time rate of change of concentration in a closed box, it will be curvilinear, so if measurements were made at successive time steps, a parabola regression was fit to the data and the slope at time zero detected (Hutchinson and Livingston, 2001). Thus, the para-curve model was made preferentially than the linear one. Otherwise, the linear model was accepted. Acceptance of the results was based upon two criteria: (1) The difference of $\mathrm{CH}_{4}$ concentration between the initial gas sample and ambient air must be within $10 \%$ and (2) the correlation coefficient $\left(\mathrm{R}^{2}\right)$ had to be $>0.90$. 
Biogeosciences Discuss., https://doi.org/10.5194/bg-2018-195

Manuscript under review for journal Biogeosciences

Discussion started: 3 May 2018

(c) Author(s) 2018. CC BY 4.0 License.

210 where $\mathrm{F}_{1}$ : the diffusive $\mathrm{CH}_{4}$ flux $\left(\mathrm{mg} \mathrm{CH} \cdot \mathrm{m}^{-2} \cdot \mathrm{h}^{-1}\right)$; $\rho$ : density of gas under the standard conditions $\left(0.714 \mathrm{~kg} \cdot \mathrm{m}^{-3}\right.$ for $\left.\mathrm{CH}_{4}\right) ; \mathrm{H}$ : height of the top of the inverted chamber to the water surface $(0.35 \mathrm{~m}$ here $) ; 273.15$ : absolute temperature at $0{ }^{\circ} \mathrm{C}$; $\mathrm{T}$ : air temperate $\left({ }^{\circ} \mathrm{C}\right)$.

214 Actually, the static floating chambers can collect both of diffusive and bubble $\mathrm{CH}_{4}$

215 emission fluxes. Bubbles caused the $\mathrm{CH}_{4}$ concentrations pulses in these chambers.

216 The average $\mathrm{CH}_{4}$ emission fluxes $\left(\mathrm{F}_{\mathrm{a}} ; \mathrm{mg} \mathrm{CH}_{4} \mathrm{~m}^{-2} \mathrm{~h}^{-1}\right)$ in the transects were calculated

217 by the following equation (2)

Where, i: the numbers of chambers ( 3 chambers here); $m$ : the sampling stations in the transect (NW: 3; NE, SW, SE: 5; DR: 4); n: the total measurement times of $\mathrm{CH}_{4}$ emission during the given time (total times of 13 in 2015, See Table S.1, S.3-6); Fm: the measured $\mathrm{CH}_{4}$ emission flux by the floating chambers.

The mass flux of $\mathrm{CH}_{4}$ via ebullition (bubble $\mathrm{CH}_{4}$ flux) is $F_{2}=\frac{C_{C H 4} \times V \times M}{A_{f} \times t \times V_{m}}$

Where $\mathrm{F}_{2}$ : the ebullitive $\mathrm{CH}_{4}$ flux $\left(\mathrm{mg} \mathrm{CH} \cdot \mathrm{m}^{-2} \cdot \mathrm{h}^{-1}\right) ; \mathrm{C}_{\mathrm{CH} 4}: \mathrm{CH}_{4}$ concentration $\left(\mu \mathrm{L} \cdot \mathrm{L}^{-1}\right)$; $\mathrm{V}$ : the accumulated headspace gas volume (L); $\mathrm{M}$ : molar weight of $\mathrm{CH}_{4}(16.04$ $\left.\mathrm{g} \cdot \mathrm{mol}^{-1}\right)$; Af: the funnel area $\left(0.14 \mathrm{~m}^{2}\right)$; $\mathrm{t}$ : the fractional number of hours between measurement; $\mathrm{V}_{\mathrm{m}}$ : the molar volume of gas at standard conditions $\left(22.4 \mathrm{~L} \cdot \mathrm{mol}^{-1}\right.$; gas samples equilibrated to room temperature before analysis) (Wik et al., 2011).

The ebullition rate $\left(\mathrm{ER} ; \mathrm{ml} \mathrm{m}^{-2} \mathrm{~h}^{-1}\right)$ reflected the speed of accumulated volume of 
Biogeosciences Discuss., https://doi.org/10.5194/bg-2018-195

Manuscript under review for journal Biogeosciences

Discussion started: 3 May 2018

(c) Author(s) 2018. CC BY 4.0 License. equation (4).

$$
E R=\frac{V}{A_{f} \times t}
$$

The parameters of $\mathrm{V}, \mathrm{A}_{\mathrm{f}}$, and $\mathrm{t}$ are given in equation (3).

\subsection{Statistical Analysis}

239 The $\mathrm{CH}_{4}$ flux values were firstly tested by the Kolmogorov-Smirnov test to judge whether these data satisfied the normal distribution. If not, these $\mathrm{CH}_{4}$ flux data would be transferred by the trigonometric function or logarithmic function to satisfy the normal distribution. Then one-way analysis of variance (ANOVA) combined with Tukey HSD test was used to analyze the seasonal and spatial variability in $\mathrm{CH}_{4}$ emission flux. The data were analyzed using the SPSS (Statistical Product and Service Solution) 18.0 statistical package.

\section{Results}

\subsection{Seasonal Variations in $\mathrm{CH}_{4}$ Emission}

Figure 3. Average $\mathrm{CH}_{4}$ emission from the 3 sampling points in the NW transect of the Jiekou town between Dec. 2014 to Jan. 2016

Note: NWP1, NWP2, and NWP3 have a distance of about $10 \mathrm{~m}, 50 \mathrm{~m}$, and $120 \mathrm{~m}$ to the south bank, respectively.

$\mathrm{CH}_{4}$ emission fluxes were measured by the static floating chambers in the upstream river in 2015, which included the ebullitive and diffusive $\mathrm{CH}_{4}$ emission. The frequency of bubble occurrence was $16.2 \%$ in the NW transect during our measurement periods (Table $\mathrm{S} 1$ ). The $\mathrm{CH}_{4}$ emission fluxes in the pelagic zones (NWP2 and NWP3) were significantly higher than those in the margin zone (NWP1), because no bubbles occurred in NWP1 (Figure 3). $\mathrm{CH}_{4}$ emission from the pelagic zones was low from February to June, but increased and fluctuated significantly from July to January, while $\mathrm{CH}_{4}$ emission from the margin zones always kept a low emission level during the measurement periods (Figure 3). 
Biogeosciences Discuss., https://doi.org/10.5194/bg-2018-195

Manuscript under review for journal Biogeosciences

Discussion started: 3 May 2018

(c) Author(s) 2018. CC BY 4.0 License.

Figure 4. Dynamics of trap bubble flux, ebullition rate, and $\mathrm{CH}_{4}$ concentration in the NW transect.

Note: The X axis of DOY, i.e., days of year, started from $3^{\text {rd }}$ August, 2016

Ebullition rates, bubble $\mathrm{CH}_{4}$ emission fluxes, and bubble $\mathrm{CH}_{4}$ concentrations measured using funnel-shaped gas traps in the NW transect, showed a similar seasonal pattern with lower emissions in spring and higher emissions in summer and autumn (Figure 4). Individual measurements ranged from 0 up to $150 \mathrm{mg} \mathrm{CH} 4 \cdot \mathrm{m}^{-2} \cdot \mathrm{h}^{-1}$. The mean bubble flux rate was $22.62 \pm 15.07 \mathrm{mg} \mathrm{CH} \mathrm{CH}_{4} \cdot \mathrm{m}^{-2} \cdot \mathrm{h}^{-1}$ in the NW transect, ranging from 0.31 to $52.27 \mathrm{mg} \mathrm{CH} \cdot \mathrm{m}^{-2} \cdot \mathrm{h}^{-1}$. Measured $\mathrm{CH}_{4}$ concentrations in the collected gas ranged from 7.32 vol. \% to 86.03 vol. \% with a mean of $59.04 \pm 23.27$ vol. \%. The average ebullition rate was $39.93 \pm 24.28 \mathrm{ml} \cdot \mathrm{m}^{-2} \cdot \mathrm{h}^{-1}$, ranging from 1.17 to $76.39 \mathrm{ml} \cdot \mathrm{m}^{-2} \cdot \mathrm{h}^{-1}$. The ebullitive $\mathrm{CH}_{4}$ flux had a significant positive correlated relationship with the ebullition rate $\left(\mathrm{R}^{2}=0.92, \mathrm{p}<0.001\right.$, Figure $\left.\mathrm{S} 1\right)$, and the bubble $\mathrm{CH}_{4}$ concentration $\left(\mathrm{R}^{2}=0.76, \mathrm{p}<0.001\right.$, Figure $\left.\mathrm{S} 2\right)$.

Figure 5. Dynamics of diffusive $\mathrm{CH}_{4}$ emission from the 3 transects of reservoir's main body in monthly scale.

Note: The different letters marked in the Fig. 5 indicated that the significant difference was found in the 3 transects during the same sampling periods.

Figure 6. Seasonal variability of $\mathrm{CH}_{4}$ emission from the 3 transects of reservoir's main body

Note: The different letters marked in the Fig. 6 indicated that the significant difference was found in the NE transects among the different seasons.

The dynamic of average diffusive $\mathrm{CH}_{4}$ fluxes fluctuated similarly among the 3 transects in the main body of the Xin'anjiang Reservoir, indicating a fluctuated upwards pattern in 2015, with exception to one sudden peak in $1^{\text {st }}$ August (DOY: 213), and one slight peak between $20^{\text {th }}$ January (DOY: 20) to $8^{\text {th }}$ March (DOY:67) in the SW lake (Figure 5). If $\mathrm{CH}_{4}$ fluxes were analyzed by seasons, seasonal variations in $\mathrm{CH}_{4}$ emission experienced a similar pattern in the NE, SW, and SE transects, which climbed continuously from the minimum in the spring to the maximum in the autumn, but decreased in the winter (Figure 6). 
Biogeosciences Discuss., https://doi.org/10.5194/bg-2018-195

Manuscript under review for journal Biogeosciences

Discussion started: 3 May 2018

(c) Author(s) 2018. CC BY 4.0 License.

Figure 7. Dynamics of diffusive $\mathrm{CH}_{4}$ emission from the downstream river.

Note: DRP1, DRP2, DRP3, and DRP4 has a distance of $0.35 \mathrm{~km}, 1 \mathrm{~km}, 4 \mathrm{~km}$, and $7 \mathrm{~km}$

downstream away from the Xin'anjiang Dam, respectively.

The average $\mathrm{CH}_{4}$ flux experienced a similar seasonal variation pattern among the 4 sites in the downstream river (Figure 7): $\mathrm{CH}_{4}$ flux decreased sharply from the maximum value in January to the minimum value in February, and subsequently fluctuated in a relatively small range (Figure 7).

\subsection{Spatial Variations in $\mathrm{CH}_{4}$ Emission}

Figure 8. Average $\mathrm{CH}_{4}$ emission from the different regions in the Xin'anjiang Reservoir.

Note: NW-B, bubble emission from the northwest transect; NW-D: diffusive emission from the northwest transect; NE, northeast lake; SW, southwest lake; SE, southeast lake; DR, downstream river. Different small letters represent the significant difference in average $\mathrm{CH}_{4}$ emission flux 
Biogeosciences Discuss., https://doi.org/10.5194/bg-2018-195

Manuscript under review for journal Biogeosciences

Discussion started: 3 May 2018

(c) Author(s) 2018. CC BY 4.0 License.

Figure 9. Average $\mathrm{CH}_{4}$ emission from the 4 sampling stations in the downstream river. Note: DRP1, DRP2, DRP3, and DRP4 has a distance of $0.5 \mathrm{~km}, 1 \mathrm{~km}, 4 \mathrm{~km}$, and $7 \mathrm{~km}$ away from the Xin'anjiang Dam, respectively. Different small letters above the column indicate the significant difference among the 4 sites at the level of $\mathrm{p}=0.05$.

No significant difference was found in $\mathrm{CH}_{4}$ emission from the margin to pelagic zone of the 3 transects in the main body of reservoir. However, the average $\mathrm{CH}_{4}$ emission flux decreased gradually in the downstream river with the distance to the Xin'anjiang Dam, with the maximum in DRP1 $\left(0.83 \pm 0.43 \mathrm{mg} \mathrm{CH}_{4} \mathrm{~m}^{-2} \mathrm{~h}^{-1}\right)$ and the minimum in DRP4 $\left(0.33 \pm 0.25 \mathrm{mg} \mathrm{CH}_{4} \mathrm{~m}^{-2} \mathrm{~h}^{-1}\right)$; the average $\mathrm{CH}_{4}$ emission flux in the DRP1 was significantly higher than those of the other 3 sampling points in the downstream river $(\mathrm{p}<0.001$; Figure 9).

\section{Discussion}

\subsection{Seasonal Variations in $\mathrm{CH}_{4}$ Emission}

The dynamics of $\mathrm{CH}_{4}$ emission from the upstream river were influenced by the interference of bubbles, and the peaks of $\mathrm{CH}_{4}$ emission flux in Figure 3 were caused by bubbles (Table S1). In our study, bubbles occurred in the deep zone (>10 m) instead of the shallow zone $(<5 \mathrm{~m}$ ), which was contrary to other studies (Rodriguez and Casper, 2018; Deshmukh et al., 2016). The high ebullitive $\mathrm{CH}_{4}$ emission from the pelagic zone was probably related to the heterogeneity of sediment accumulation (DelSontro et al., 2010, 2011) while no or less sediment accumulation occurred along the margins of the reservoir (Mendonça et al., 2014).

The seasonal variability of $\mathrm{CH}_{4}$ emission from the main body of Xin'anjiang Reservoir denied the hypothesis (1), because the maximum $\mathrm{CH}_{4}$ emission occurred in autumn instead of summer in the 3 transects of the main body, although the significant difference of seasonal variability in $\mathrm{CH}_{4}$ emission was only found in the NE lake (Figure 6). $\mathrm{CH}_{4}$ fluxes had little relationship with air or water temperature after a linear correlated analysis. The explanation to the variability pattern of $\mathrm{CH}_{4}$ emission flux in Figure 6 was probably related with the dynamics of DO concentration in the 
Biogeosciences Discuss., https://doi.org/10.5194/bg-2018-195

Manuscript under review for journal Biogeosciences

Discussion started: 3 May 2018

(c) Author(s) 2018. CC BY 4.0 License.

water surface. Unfortunately, the DO values were not measured during our sampling campaigns. But a study on the dynamic distributions of DO in the 6 stations of Xin'anjiang Reservoir (3 stations overlap with this study) from Jan. 2011 and Dec. 2012 indicated that the maximum DO at surface layer was found in spring and the minimum value appeared in autumn, because phytoplankton started to breed in the proper temperature and light conditions at the surface layer in spring, which would release plenty of oxygen in the water column, while respiration overweight photosynthesis in autumn (Yin et al., 2014). The variability pattern of DO was contrary to the dynamics of $\mathrm{CH}_{4}$ flux in Figure $6 . \mathrm{CH}_{4}$ was mineralized to $\mathrm{CO}_{2}$ by methanotrophic bacteria under aerobic water column (Schubert et al., 2012).

An obvious peak $\left(0.25 \pm 0.15 \mathrm{mg} \mathrm{CH}_{4} \mathrm{~m}^{-2} \mathrm{~h}^{-1}\right)$ was observed in $1^{\text {st }}$ August (DOY: 213) in the SW lake (Figure 5), and $\mathrm{CH}_{4}$ fluxes in the two margin sampling points (i.e., SWP1 and SWP2) were $0.47 \pm 0.11 \mathrm{mg} \mathrm{CH}_{4} \mathrm{~m}^{-2} \mathrm{~h}^{-1}$ and $0.35 \pm 0.081 \mathrm{mg} \mathrm{CH}_{4} \mathrm{~m}^{-2} \mathrm{~h}^{-1}$, respectively (Table S4), which had a large contribution to the $\mathrm{CH}_{4}$ emission peak. The high $\mathrm{CH}_{4}$ fluxes from the margin zone were likely attributed to the decomposed vegetation in the littoral zone when the water level increased to the highest level $(104.4 \mathrm{~m}$ ) in July (Figure 1). It is worth mentioning that the bank of the SW transect is gentle and soil slope and the banks of NE and SE transect are steep and rock slope. So vegetation could grow in the littoral zone of SW transect when the water level was low enough in spring. Such $\mathrm{CH}_{4}$ emission peaks were also reported in the littoral zone of Miyun Reservoir and Three Gorges Reservoir (Yang et al., 2012, 2014).

Figure 10. The discharge flow in the downstream river below the dam at 9:00 a.m. during the measurement periods

The downstream $\mathrm{CH}_{4}$ emissions (included the degassing at the turbines) are proportional to the streamflow in the previous studies (Fearnside and Pueyo, 2012). The degassing emissions at the turbines of Xing'anjiang Dam were not measured by the difference in $\mathrm{CH}_{4}$ concentrations at the turbine intake and in the water below the 
Biogeosciences Discuss., https://doi.org/10.5194/bg-2018-195

Manuscript under review for journal Biogeosciences

Discussion started: 3 May 2018

(c) Author(s) 2018. CC BY 4.0 License.

dam, because about the $500 \mathrm{~m}$ upstream and downstream of the dam was forbidden to access to make sure the Xin'anjiang Dam safe. However, $\mathrm{CH}_{4}$ emissions from the 4 sampling points, with the different distances to the dam, were measured 13 times in 2015 (Figures 7). The minimum value $\left(0.19 \pm 0.11 \mathrm{mg} \mathrm{CH}_{4} \mathrm{~m}^{-2} \mathrm{~h}^{-1}\right)$ appeared in February, which was likely caused by the low the discharged flow $\left(275 \mathrm{~m}^{3} \mathrm{~s}^{-1}\right)$ at the downstream river during the measurement periods (Figure 10). Although the variability pattern of $\mathrm{CH}_{4}$ emission was not completely consistent with the streamflow in the downstream river (Figures 7, 10), the streamflow below the dam still account for $25.3 \%$ seasonal variability of $\mathrm{CH}_{4}$ emission in the DRP1 (Figure $\mathrm{S} 3, \mathrm{p}<0.05$, $\mathrm{r}=0.50$ ), which was about 500m downstream of the Xin'anjiang Dam.

\subsection{Spatial Variations in $\mathrm{CH}_{4}$ Emission}

Figure 11. Schematic diagram of the spatiotemporal variability in $\mathrm{CH}_{4}$ emission from Xin'anjiang

The results were confirmed the hypothesis (2), with a high emission level in upstream and downstream river, and a low emission level in the main reservoir body (Figure 11). The obviously high $\mathrm{CH}_{4}$ emission from the upstream river was contributed by the bubbles (Figures 3, 4, Table S2). However, few bubble was trapped in the floating chambers in the main body of the reservoir and the downstream river below the dam in 2015 (Figures 6, 7). The $\mathrm{CH}_{4}$ ebullition fluxes in inflow rivers or upstream rivers were also reported in the many other reservoirs (DelSontro et al., 2011, Musenze et al., 2014; Beaulieu et al., 2014). Besides the bubble $\mathrm{CH}_{4}$ fluxes, the diffusive $\mathrm{CH}_{4}$ fluxes contributed to $30 \%$ of the total $\mathrm{CH}_{4}$ flux there, and were more than 10 times and 2 times higher than those from the main body and the downstream river, respectively (Figure 8), which was attributed to the fast water velocity, shallow water depths, and a large amount of allochthonous carbon input. Water flow was fast in the upstream river during the heavy rainy days (especially in June), which carried plenty of allochthonous organic matter constantly. The deepest zone was about $20 \mathrm{~m}$ in the NW 
Biogeosciences Discuss., https://doi.org/10.5194/bg-2018-195

Manuscript under review for journal Biogeosciences

Discussion started: 3 May 2018

(c) Author(s) 2018. CC BY 4.0 License.

points in the 3 transects of the main body. The shallow water depths would reduce the transport path for small $\mathrm{CH}_{4}$ molecule, and more $\mathrm{CH}_{4}$ would reach the water-air interface because the less amount of $\mathrm{CH}_{4}$ was oxidized at the oxic layer by the methanotrophic bacteria (Schubert et al., 2012).

Table 1. Previously reported $\mathrm{CH}_{4}$ emission from temperate and subtropical reservoirs

The average $\mathrm{CH}_{4}$ emission fluxes from the upstream river of Xin'anjiang Reservoir were higher than that of Three Gorges Reservoir, China, Douglas Lake, USA, Nam Theun 2 Reservoir, Laos, and Eguzon Reservoir, France, but lower than that in William H. Harsha Lake, USA, Gold Creek and Little Nerang Reservoir, Australia (Table 1). Diffusive $\mathrm{CH}_{4}$ emission was measured from the upstream rivers of Three Gorges Reservoir, Douglas Lake, Nam Theun 2 Reservoir, and Eguzon Reservoir, because no bubble or a few bubbles were observed in the upstream rivers of the 4 reservoirs. A significant high $\mathrm{CH}_{4}$ emission from the upstream river in Xin'anjiang Reservoir contributed from bubbles, which was similar to the situations in the upstream rivers of Harsha Lake, Gold Creek, and Little Nerang Reservoir. Furthermore, The diffusive average $\mathrm{CH}_{4}$ emission from the main body of Xin'anjiang Reservoir $\left(0.10 \pm 0.07 \mathrm{mg} \mathrm{CH} \cdot \mathrm{m}^{-2} \cdot \mathrm{h}^{-1}\right)$ was within the range of $\mathrm{CH}_{4}$ emission level reported in the other reservoirs in China (mean: $0.22 \pm 0.18 \mathrm{mg} \mathrm{CH}_{4} \cdot \mathrm{m}^{-2} \cdot \mathrm{h}^{-1}$; $\mathrm{Li}$ et al., 2015), but the $\mathrm{CH}_{4}$ emission was 1-2 orders of magnitude lower than that from the reservoirs in Australia and Laos (William H. Harsha Lake, Gold Creek Reservoir, Little Narang Reservoir, Nam Leuk and Nam Theun 2 Reservoir), comparable to other temperate or subtropical reservoirs listed in Table 1, except Douglas Lake and 5 small reservoirs in Jiangxi Province, China.

Flooded barren soils, dendritic reservoir shape, and aerobic water body probably caused the relative low $\mathrm{CH}_{4}$ emission from the Xin'anjiang Reservoir. Before the water storage of the Xin'anjiang Reservoir, strictly clearing activities were done under the elevation of $70 \mathrm{~m}$. The left organic carbon would decompose in the first several 
Biogeosciences Discuss., https://doi.org/10.5194/bg-2018-195

Manuscript under review for journal Biogeosciences

Discussion started: 3 May 2018

(c) Author(s) 2018. CC BY 4.0 License.

years after impoundment (Abril et al., 2005). After all, Xin'anjiang Reservoir was an old reservoir with an age of 56-58 years, thus the remaining flooded organic carbon had little contribution to $\mathrm{CH}_{4}$ emission. Moreover, chlorophyll-a and water depth controlled the reservoirs $\mathrm{CH}_{4}$ emissions (Deemer et al., 2016). The ranges were in the range of 1 to $3 \mu \mathrm{g} / \mathrm{L}$ for chlorophyll-a and 10 to $23 \mu \mathrm{g} / \mathrm{L}$ for total phosphorus in the epilimnion of Xin'anjiang Reservoir, respectively (Li et al. 2011; Yu et al., 2010), which was an oligotrophic reservoir, according to the classification standard of nutrition for the tropical/subtropical reservoirs (Cunha et al., 2013). Besides, the average water depth was about $34 \mathrm{~m}$ in the Xin'anjiang Reservoir, and the small $\mathrm{CH}_{4}$ molecules were difficult to pass through such deep path. Furthermore, the Xin'anjiang Reservoir was dendritic shape, so allochthonous organic carbon mainly deposited in the sediments of NW lake (Yu et al., 1988, Figure 1), which had little contribution to $\mathrm{CH}_{4}$ emission from the main reservoir body. In addition, there was no anoxic layer in Xin'anjiang Reservoir (Zhang et al., 2015), thus the methanotrophic bacteria could oxidize the dissolve $\mathrm{CH}_{4}$ at the aerobic conditions when they diffused to the atmosphere (Yang et al., 2014b). All of these above factors combined together lead to a relative low $\mathrm{CH}_{4}$ emission flux in the reservoir's main body.

A significantly higher $\mathrm{CH}_{4}$ emission was observed in the downstream river than that in the water surfaces before the dam (Figure 8), which was probably released from the dissolved $\mathrm{CH}_{4}$ in reservoir's hypolimnions (Abril et al., 2005). Our data set did not include the dissolved $\mathrm{CH}_{4}$ concentration in different depths before the dam, but previous related studies reported the dissolved $\mathrm{CH}_{4}$ concentration increased with the depth before the dam (Abril et al., 2005). The dissolved $\mathrm{CH}_{4}$ would release to the atmosphere because of the differences in pressure, temperature, and turbulence when the water passed through the turbines and spillways (Yang et al., 2014b). Strong turbulence made the dissolved $\mathrm{CH}_{4}$ emission into the atmosphere in the downstream river below the Xin'anjiang Dam. However, the diffusive $\mathrm{CH}_{4}$ flux dropped with the distances to the dam, with an obvious higher $\mathrm{CH}_{4}$ flux in the DRP1 (Figure 9), which was likely related to the decrease of turbulence strength with a distance to the dam 
Biogeosciences Discuss., https://doi.org/10.5194/bg-2018-195

Manuscript under review for journal Biogeosciences

Discussion started: 3 May 2018

(c) Author(s) 2018. CC BY 4.0 License.

and the explosive release of $\mathrm{CH}_{4}$ gas right after the turbines (degassing). The similar pattern of $\mathrm{CH}_{4}$ emission was also observed in the downstream rivers of Balbina, Samuel, Petit-Saut, and Nam Theun 2 reservoirs, and $\mathrm{CH}_{4}$ emission flux in $30 \mathrm{~km}$ was close to the natural rivers nearby (Kemenes et al., 2007; Deshmukh et al., 2016; Guérin et al., 2006).

\section{Conclusion}

The $\mathrm{CH}_{4}$ fluxes data values obtained in Xin'anjiang Reservoir showed the its different seasonal variability: $\mathrm{CH}_{4}$ emission from the main reservoir body had a high emission level in autumn, a low level in spring, and a similar medium levels in summer and winter; In the main upstream river of the reservoir, $\mathrm{CH}_{4}$ emission was low in the first half year, but high in the second half year; $\mathrm{CH}_{4}$ emission from the downstream river was largely influenced by the streamflow below the dam. In the spatial scale, $\mathrm{CH}_{4}$ emission had a high emission level in the upstream river and downstream river, but a low emission level in the reservoir's main body. A thoroughly investigation should be carried out in the different reservoir regions for a long-term basis to discover the spatiotemporal variability in $\mathrm{CH}_{4}$ emission flux in a hydroelectric reservoir system, which could avoid the error of estimating the $\mathrm{CH}_{4}$ emission incorrectly. The rules on the temporal and spatial variability in $\mathrm{CH}_{4}$ emission and its potential influencing variables would be helpful to take proper measures to reduce the greenhouse gases emissions from the hydroelectric reservoir system in terms of the reservoir's management.

\section{Supplementary Materials:}

Figure S1: Positive relationships between the ebullitive $\mathrm{CH}_{4}$ emission and ebullition rates in the

NW transect.

Figure S2. Positive relationship between the bubble $\mathrm{CH}_{4}$ emission and bubble $\mathrm{CH}_{4}$ concentration 
Biogeosciences Discuss., https://doi.org/10.5194/bg-2018-195

Manuscript under review for journal Biogeosciences

Discussion started: 3 May 2018

(c) Author(s) 2018. CC BY 4.0 License.

sampling points of NW transect from Dec. 2014 to Jan. 2016.

Table S2. Complete dataset of the measured ebullitive $\mathrm{CH}_{4}$ fluxs, ebullition rates, and $\mathrm{CH}_{4}$

concentrations by the inverted funnels in the 26 sampling stations of the NW transect during Aug.

2016 to Nov. 2017.

Table S3. The measured $\mathrm{CH}_{4}$ emission fluxes by the floating chambers at the 5 sampling points of

NE transect in 2015.

Table S4. Complete dataset of the measured $\mathrm{CH}_{4}$ emission fluxes by the floating chambers at the 5 sampling points of SW transect from Dec. 2014 to Dec. 2015.

Table S5. Complete dataset of the measured $\mathrm{CH}_{4}$ emission fluxes by the floating chambers at the 5 sampling points of SE transect from Jan. 2015 to Jan. 2016.

Table S6. Complete dataset of the measured $\mathrm{CH}_{4}$ emission fluxes by the floating chambers at the 4 sampling points of downstream river from Dec. 2014 to Dec. 2015.

Acknowledgements: The study was funded by the National Natural Science Foundation of China (41303065), the Project of Zhejiang Scientific and Technological Plan (2015F30001) and Zhejiang Hangzhou Urban Forest Ecosystem Research Station. We thank for the Xin'anjiang hydropower plant to provide the streamflow data below the dam. Data presented in this work can be found in the supporting information.

Conflicts of Interest: The authors declare no conflict of interest.

\section{References}

Abril, G., Guérin, F., Richard, S., Delmas, R., Galy-Lacauz, C., Gosse, P., Tremblay, A., Varfalvy, L., Dos Santos, M., Matvienko, B.: Carbon dioxide and methane emissions and the carbon budget of a 10-year old tropical reservoir (Petit Saut, French Guiana), Global Biogeochem. Cy., 19, GB4007, 2005. methane emissions offset the continental carbon sink, Science, 50, 2011. 
Biogeosciences Discuss., https://doi.org/10.5194/bg-2018-195

Manuscript under review for journal Biogeosciences

Discussion started: 3 May 2018

(c) Author(s) 2018. CC BY 4.0 License.

emissions from a midlatitude reservoir draining an agricultural watershed. Environ.

Sci. Technol., 48, 11100-11108, 2014.

Chanudet, V., Descloux, S., Harby, A., Sundt, H., Hansen, B., Brakstad, O., Serça, D., Guérin, F.: Gross $\mathrm{CO}_{2}$ and $\mathrm{CH}_{4}$ emissions from the Nam Ngum and Nam Leuk sub-tropical reservoirs in Lao PDR, Sci. Total Environ., 409, 5382-5391, 2011.

Cunha, D., Calijuri, M., Lamparelli, M.: A trophic state index for tropical/ subtropical reservoirs (TSI ${ }_{\text {tsi }}$ ), Ecol. Eng., 60, 126-134, 2013.

Deemer, B., Harrison, J., Li, Y., Beaulieu, J., Delsontro, T., Barros, N., Bezerra-neto, J., Powers, S., Dos Santos, M., Arie Vionk, J.: Greenhouse gas emissions from reservoir water surfaces: a new global synthesis, Bioscience, 66, 949-964, 2016.

DelSontro, T., McGinnis, D., Sobek, S., OStrovsky, I., Wehrli, B.: Extreme methane emissions from a Swiss hydropower reservoir: Contribution from bubbling sediments, Environ. Sci. Technol., 44, 2419-2425, 2010.

DelSontro, T., Kunz, M., Kimpter, T., Wüest, A., Wehrli, B., Senn, D.: Spatial heterogeneity of methane ebullition in a large tropical reservoir, Environ. Sci. Technol., 45, 9866-9873, 2011.

DelSontro, T., Boutet, L., St-Pierre, A., Del Giorgio, P., Prairie, Y.: Methane ebullition and diffusion from northern ponds and lakes regulated by the interaction between temperature and system productivity, Limnol. Oceanogr., 61, S62-S77, 2016.

Descloux, S., Chanudet, V., Serça, V., Guérin, F.: Methane and nitrous oxide annual emissions from an old eutrophic temperature reservoir. Sci. Total Environ., 598, 959-972, 2017.

Deshmukh, C., Guérin, F., Labat, D., Pighini, S., Vongkhamsao, A., Guedant, P., Rode, W., Godon, A., Chanudet,V., Delscloux, S.: Serça D. Low methane $\left(\mathrm{CH}_{4}\right)$ emissions downstream of a monomictic subtropical hydroelectric reservoir (Nam Theun 2, Lao PDR), Biogeosciences, 13, 1919-1932, 2016.

Fearnside, P., Pueyo, S.: Greenhouse-gas emissions from tropical dams, Nat. Clim.

Change, 2, 382-384, 2012. 
Biogeosciences Discuss., https://doi.org/10.5194/bg-2018-195

Manuscript under review for journal Biogeosciences

Discussion started: 3 May 2018

(c) Author(s) 2018. CC BY 4.0 License.

Guérin, F., Abril, G., Richard, S., Burban, B., Reynourd, C., Seyler, P., Delmas, R.: Methane and carbon dioxide emissions from tropical reservoirs: significance of downstream rivers, Geophys. Res. Lett., 33, L21407, 2006.

Guérin, F., Deshmukh, C., Labat, D., Pighini, S., Vongkhamsao, A., Guédant, P., Rode, W., Godon, A., Chanudet, V., Descloux, S., Serça, D.: Effect of sporadic destratification, seasonal overturn, and artificial mixing on $\mathrm{CH}_{4}$ emissions from a subtropical hydroelectric reservoir, Biogeosciences, 13, 3647-3663, 2016.

Hutchinson, G., Livingston, G.: Vents and seals in non-steady-state chambers used for measuring gas exchange between soil and atmosphere, Eur. J. Soil Sci., 52, 675-682, 2001.

Jacinthe, P., Filippelli, G., Tedesco, L., Raftis, R.: Carbon storage and greenhouse gases emission from a fluvial reservoir in an agricultural landscape, Catena, 94, 53-63, 2012.

Jiang, X., Zhang, L., Yao, X., Xu, H., Li, M.: Greenhouse gas flux at reservoirs of Jiangxi Province and its influencing factors, J. Lake Sci., 29, 1000-1008, 2017.

Juutinen, S., Alm, J., Martikainen, P., Silvola, J.: Effect of spring flood and water level drawn-down on methane dynamics in the littoral zone of boreal lakes, Freshwater Bio., 46, 855-869, 2001.

Kemenes, A., Forsberg, B., Melack, J.: Methane release below a tropical hydroelectric dam, Geophys. Res. Lett., 34, L12809, 2007.

Li, P., Shi, W., Liu, Q., Yu, Y., He, G., Chen, L., Ren, L., Hong, R.: Spatial and temporal distribution patterns of chlorophyll-a and the correlation analysis with environmental factors in Lake Qiandao, J. Lake Sci., 23, 568-574, 2011.

Li, Y., Zhang,Q., Bush, R., Sullivan, L.: Methane and $\mathrm{CO}_{2}$ emission from China's hydroelectric reservoirs: a new quantitative synthesis, Environ. Sci. Pollut. Res., $22,5325-5339,2015$.

Maeck, A., Hofmann, H., Lorke, A.: Pumping methane out of aquatic sediments-ebullition forcing mechanisms in an impounded river, Biogeosciences, 11, 2925-2938, 2014.

Mendonça, R., Kosten, S., Sobek, S., Cole, J., Bastos, A., Albuquerque, A., Cardoso, 
Biogeosciences Discuss., https://doi.org/10.5194/bg-2018-195

Manuscript under review for journal Biogeosciences

Discussion started: 3 May 2018

(c) Author(s) 2018. CC BY 4.0 License.

S., Roland, F.: Carbon sequestration in a large hydroelectric reservoir: an integrative seismic approach, Ecosystems, 17, 430-441, 2014.

Musenze, R., Grinham, A., Werner, U., Gale, D., Sturm, K., Udy, J., Yuan, Z.: Assessing the spatial and temporal variability of diffusive methane and nitrous oxide emissions from subtropical freshwater reservoirs, Environ. Sci. Technol., 48, 14499-14507, 2014.

Mosher, J., Fortner, A., Phillips, J., Bevelhimer, M., Stewart, A., Troia, M.: Spatial and temporal correlates of greenhouse gas diffusion from a hydropower reservoir in the southern United States, Water, 7, 5910-5927, 2015.

Natchimuthu, S., Sundgren, I., Gålfalk, M., Klemedtsson, L., Crill, P., Danielsson, A., Bastviekn, D.: Spatio-temporal variability of lake $\mathrm{CH}_{4}$ fluxes and its influence on annual whole lake emission estimates, Limnol. Oceanogr., 61, S13-S26, 2016.

Ometto, J., Cimbleris, A., Dos Santos, M., Rosa, L., Abe, O., Tundisi, J., Stech, J., Barros, N., Roland, F.: Carbon emission as a function of energy generation in hydroelectric reservoirs in Brazilian dry tropical biome, Energ. Policy, 58, 109-116, 2013.

Rodriguez, M., Casper, P.: Greenhouse gas emissions from a semi-arid tropical reservoir in northeastern Brazil, Reg. Environ. Change, 18, 1-12, 2018.

Sobek, S., DelSontro, T., Wangfun, N., Wehrli, B.: Extreme organic carbon burial fuels intense methane bubbling in a temperate reservoir, Geophys. Res. Lett., 39, L01401, 2012.

Schubert, C., Diem, T., Eugster, W.: Methane emissions from a small wind shielded lake determined by eddy covariance, flux chambers, anchored funnels, and boundary model calculations: a comparison, Environ. Sci. Technol., 46, 4515-4522, 2012.

Soumis, N., Duchemin, E., Canuel, R., Lucotte, M.: Greenhouse gas emissions from reservoirs of the western United States, Global Biogeochem. Cy., 18, GB3022, 2004.

Sturm, K., Yuan, Z., Gibbes, B., Grinham, A.: Methane and nitrous oxide sources and emissions in a subtropical freshwater reservoir, South East Queenland, Australia, 
Biogeosciences Discuss., https://doi.org/10.5194/bg-2018-195

Manuscript under review for journal Biogeosciences

Discussion started: 3 May 2018

(c) Author(s) 2018. CC BY 4.0 License.

Biogeosciences, 11, 5245-5248, 2014.

Wang, X., He, Y., Yuan, X., Chen, H., Peng, C., Yue, J., Zhang, Q., Diao, Y., Liu, S.: Greenhouse gases concentrations and fluxes from subtropical small reservoirs in relation with watershed urbanization, Atmos. Environ., 154, 225-235, 2017.

Wik, M., Crill, P., Bastviken, D., Danielsson, A., Norbäck, E.: Bubbles trapped in arctic lake ice: potential implications for methane emissions, J. Geophys. Res., 116, G03044, 2011.

Wik, M., Crill, P., Varner, R., Bastviken, D.: Multiyear measurements of ebullitive methane flux from three subarctic lakes, J. Geophys. Res., 118, 1307-1321, 2013.

Yang, M., Li, H., Ting, L., Zhou, Y., Lu, C., Li, L., Lei, G., Wang, J., Lu, X.: Spatial-temporal characteristics of methane emission flux and its influence factors at Miyun Reservoir in Beijing, Wetland Sci., 9, 191-197, 2011.

Yang, L., Lu, F., Wang, X., Duan, X., Song, W., Sun, B., Chen, S., Zhang, Q., Hou, P., Zheng, F., Zhang, Y., Zhou, X., Zhou, Y., Ouyang, Z.: Surface methane emissions from different land use types during various water levels in three major drawdown areas of the Three Gorges Reservoir, J. Geophys. Res., 117, 10109, 2012.

Yang, L., Lu, F., Wang, X., Duan, X., Song, W., Sun, B., Zhang, Q., Zhou, Y.: Spatial and seasonal variability of diffusive methane emissions from the Three Gorges Reservoir, J. Geophys. Res., 118, 471-481, 2013.

Yang, M., Geng, X., Grace, J., Lu, C., Zhu, Y., Zhou, Y., Lei, G.: Spatial and seasonal $\mathrm{CH}_{4}$ flux in the littoral zone of Miyun Reservoir near Beijing: the effects of water level and its fluctuation, Plos one, 9, e94275, 2014a.

Yang, L., Lu, F., Zhou, X., Wang, X., Duan, X., Sun, B.: Progress in the studies on greenhouse gas emissions from reservoirs, Acta Ecol. Sin., 34, 204-212, 2014 b.

Yin, Y., Wu, Z., Liu, M., He, J., Yu, Z.: Dynamic distributions of dissolved oxygen in lake Qiandaohu and its environmental influence factors, Environ. Sci., 35, 2539-2546, 2014.

Yu, Y. The Analysis of the deposits of the Xin'anjiang Reservoir (in Chinese with English Abstract), J. East China Norm. Univ. (Nat. Sci.), 3, 77-84, 1988.

Yu, Y., Ren, L., Liu, Q., Shi, W., Liu, G., He, G., Chen, L., Hong, R.: Temporal and 
Biogeosciences Discuss., https://doi.org/10.5194/bg-2018-195

Manuscript under review for journal Biogeosciences

Discussion started: 3 May 2018

(c) Author(s) 2018. CC BY 4.0 License.

661 spatial distribution of nutrients and influence factors of Lake Qiandao during 662 2007-2008, Wetland Sci., 22, 684-692, 2010.

663 Yang, L., Lu, F., Zhou, X., Wang, X., Duan, X., Sun, B.: Progress in the studies on 664 greenhouse gas emissions from reservoirs, Acta Ecol. Sin., 34, 204-212, 2014.

665 Zhang, Y., Wu, Z., Liu, M., He, J., Shi, K., Zhou, Y., Wang, M., Liu, X.: Dissolved 666 oxygen stratification and response to thermal structure and long-term climate 667 change in a large and deep subtropical reservoir (Lake Qiandaohu, China), Water 668 Res., 75, 249-258, 2015.

669 Zhao, Y., Wu, B., Zeng, Y.: Spatial and temporal patterns of greenhouse gas emissions 670 from Three Gorges Reservoir of China, Biogeosciences, 10, 1219-1230, 2013.

671 Zheng, H., Zhao, X., Zhao, T., Chen, F., Xu, W., Duan, X., Wang, X., Ouyang, Z.: 672 Spatial-temporal variations of methane emissions from the Ertan hydroelectric 673 reservoir in southwest China, Hydrol. Process., 25, 1391-1396, 2011. 
Biogeosciences Discuss., https://doi.org/10.5194/bg-2018-195

Manuscript under review for journal Biogeosciences

Discussion started: 3 May 2018

(c) Author(s) 2018. CC BY 4.0 License.

676 Figure 1. Dynamics of precipitation, evaporation, air temperature, and water level in 677 the Xin'anjiang Reservoir region

678 Figure 2. The distribution of the sampling transects and sampling sites in the 679 Xin'anjiang Reservoir

680 Figure 3. Average CH4 emission from the 3 sampling points in the NW transect of the 681 Jiekou town between Dec. 2014 to Jan. 2016

682 Figure 4. Dynamics of trap bubble flux, ebullition rate, and $\mathrm{CH}_{4}$ concentration in the $683 \quad$ NW transect

684 Figure 5. Dynamics of diffusive $\mathrm{CH}_{4}$ emission from the 3 transects of reservoir's main 685 body in monthly scale

686 Figure 6. Seasonal variability of $\mathrm{CH}_{4}$ emission from the 3 transects of reservoir's 687 main body

688 Figure 7. Dynamics of diffusive $\mathrm{CH}_{4}$ emission from the downstream river

689 Figure 8. Average $\mathrm{CH}_{4}$ emission from the different regions in the Xin'anjiang 690 Reservoir.

691 Figure 9. Average $\mathrm{CH}_{4}$ emission from the 4 sampling stations in the downstream river.

692 Figure 10. The discharge flow in the downstream river below the dam at 9:00 a.m. 693 during the measurement periods

694 Figure 11. Schematic diagram of the spatiotemporal variability in $\mathrm{CH}_{4}$ emission from 695 Xin'anjiang Reservoir

696 
Biogeosciences Discuss., https://doi.org/10.5194/bg-2018-195

Manuscript under review for journal Biogeosciences

Discussion started: 3 May 2018

(c) Author(s) 2018. CC BY 4.0 License.

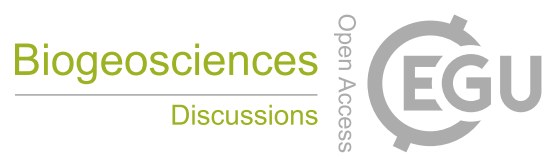

\section{(c) (i)}

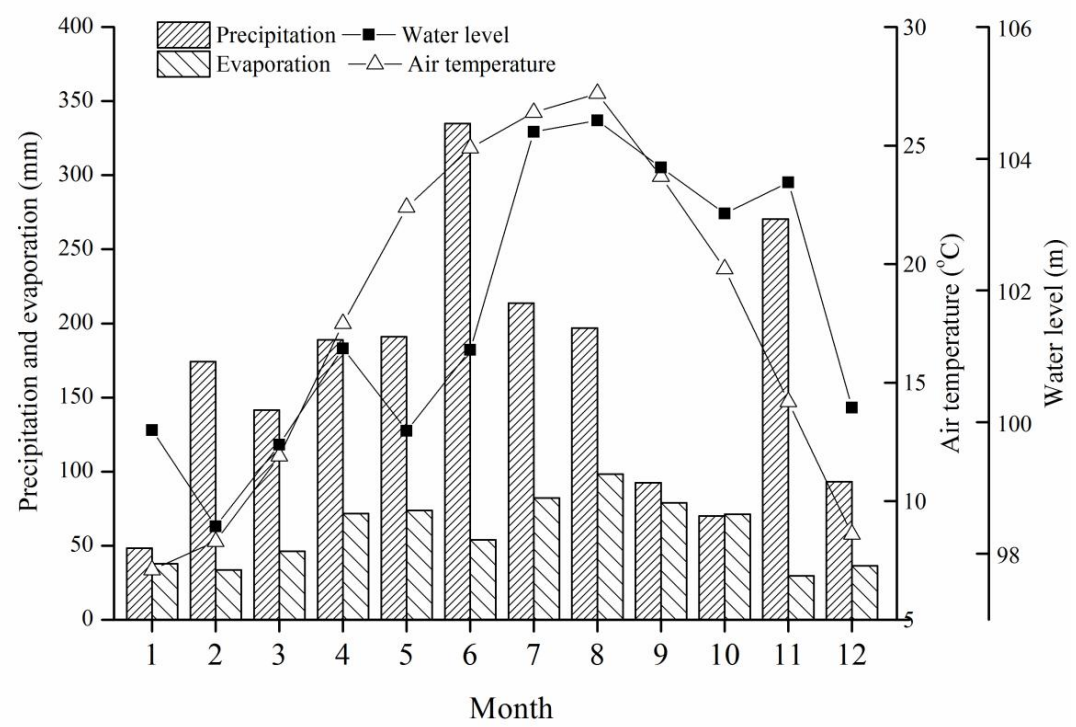

697

698

Figure 1

699 
Biogeosciences Discuss., https://doi.org/10.5194/bg-2018-195

Manuscript under review for journal Biogeosciences

Discussion started: 3 May 2018

(c) Author(s) 2018. CC BY 4.0 License.

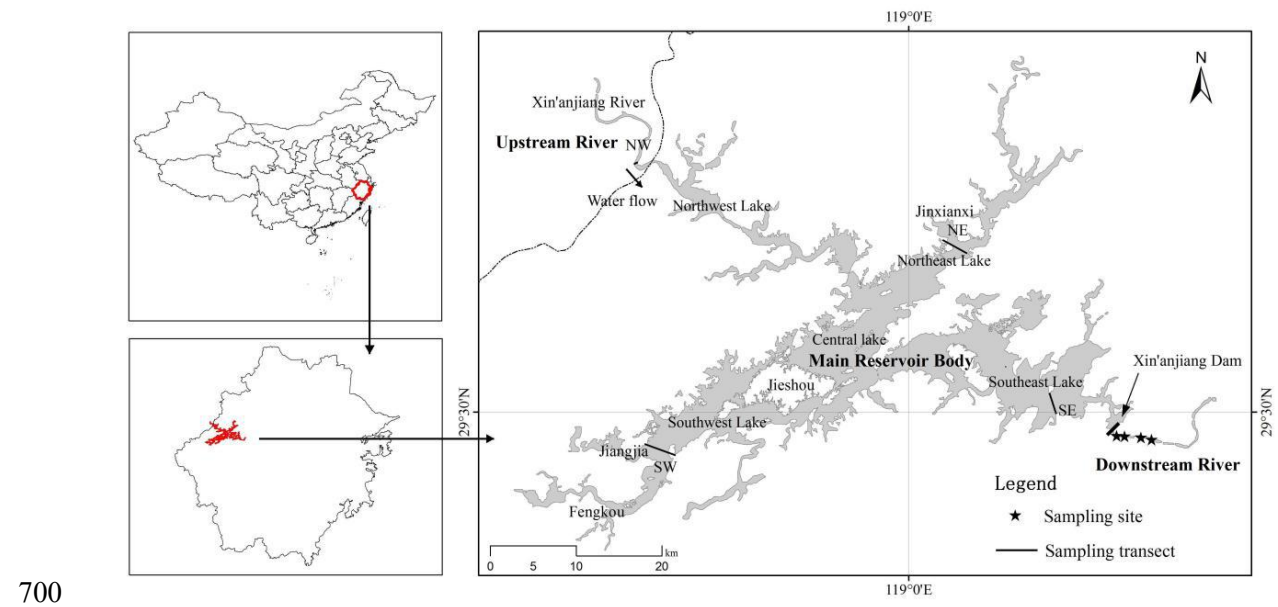

701

Figure 2

702 
Biogeosciences Discuss., https://doi.org/10.5194/bg-2018-195

Manuscript under review for journal Biogeosciences

Discussion started: 3 May 2018

(c) Author(s) 2018. CC BY 4.0 License.

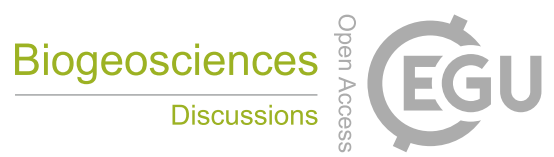

(c) (i)

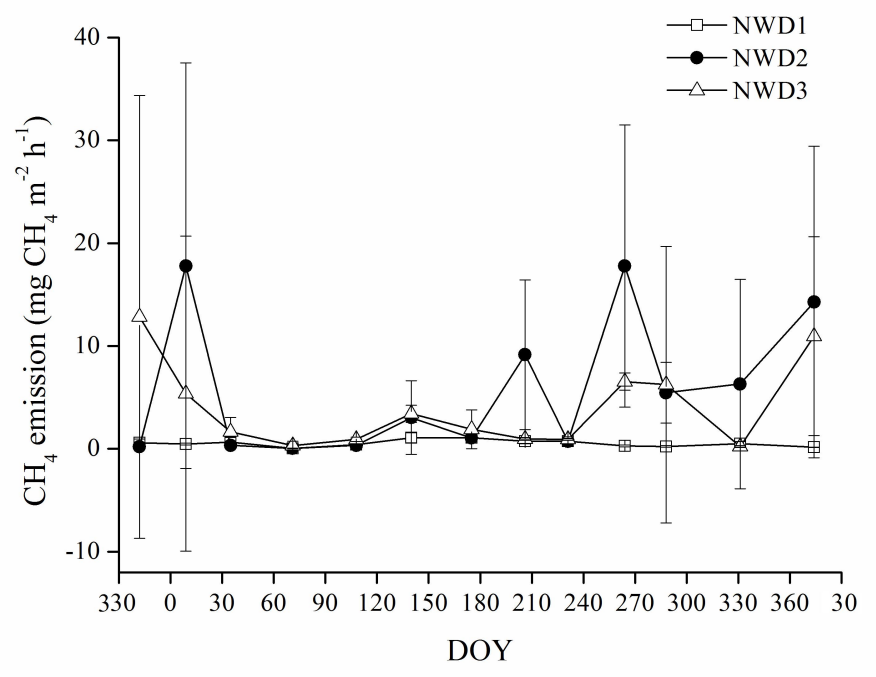

703

704

Figure 3

705 
Biogeosciences Discuss., https://doi.org/10.5194/bg-2018-195

Manuscript under review for journal Biogeosciences

Discussion started: 3 May 2018

(c) Author(s) 2018. CC BY 4.0 License.

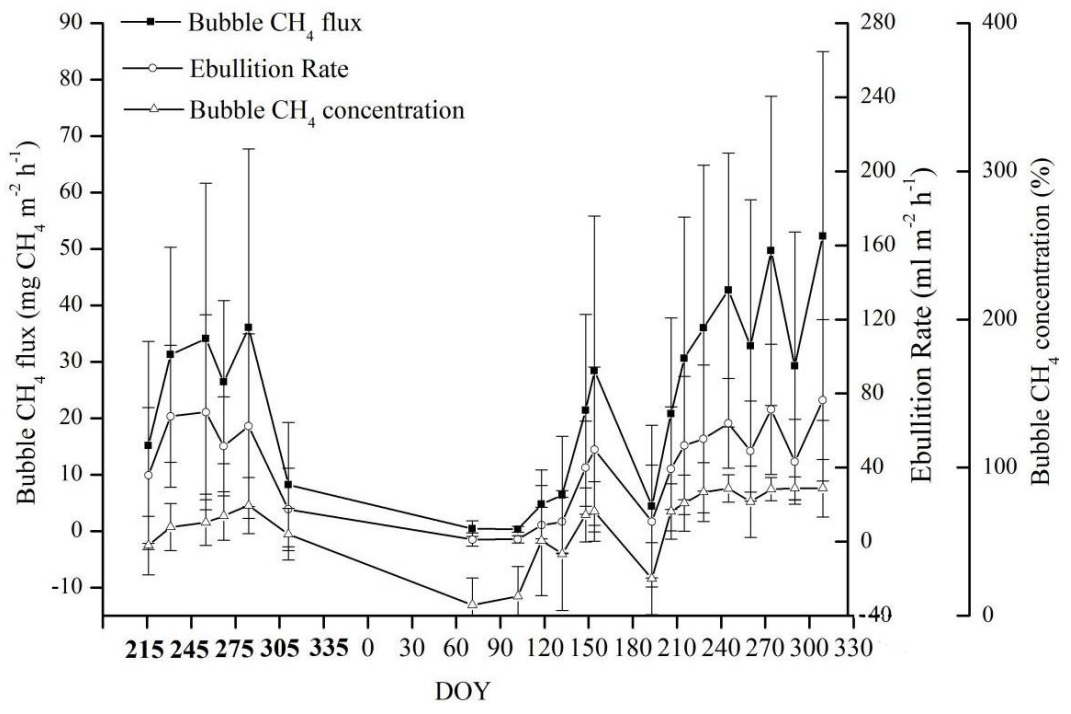

Figure 4

708 
Biogeosciences Discuss., https://doi.org/10.5194/bg-2018-195

Manuscript under review for journal Biogeosciences

Discussion started: 3 May 2018

(c) Author(s) 2018. CC BY 4.0 License.

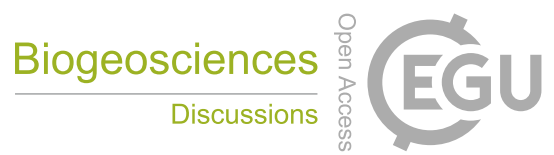

(c)

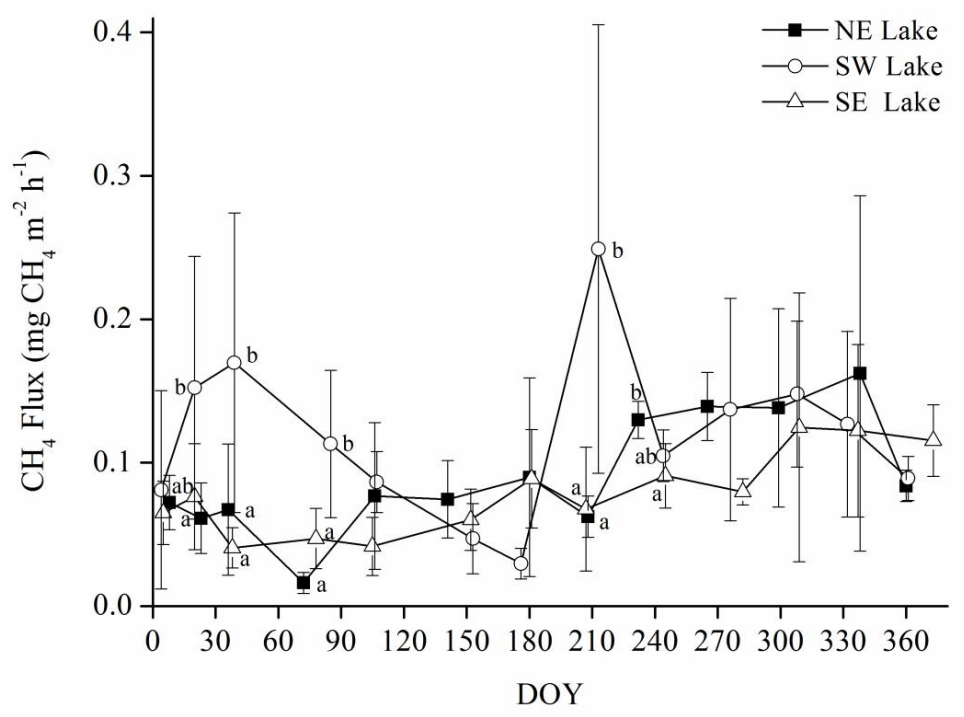

709

710

Figure 5

711 
Biogeosciences Discuss., https://doi.org/10.5194/bg-2018-195

Manuscript under review for journal Biogeosciences

Discussion started: 3 May 2018

(c) Author(s) 2018. CC BY 4.0 License.

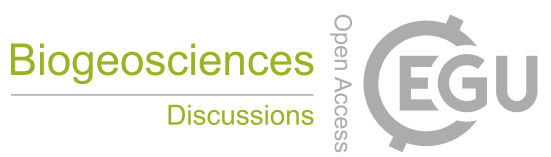

(c) (i)

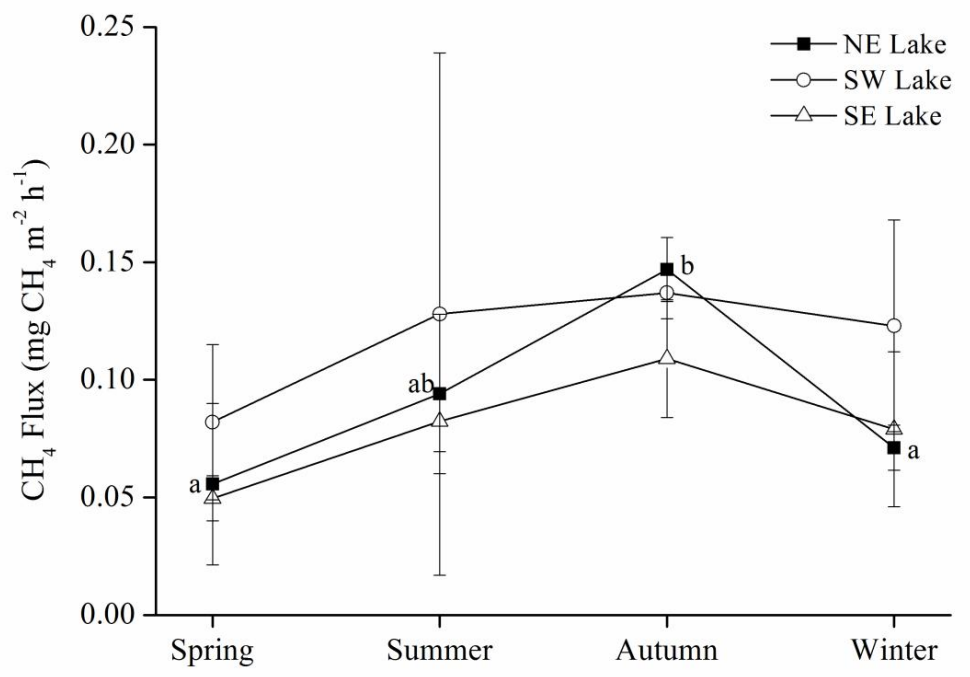

712

713

Figure 6

714 
Biogeosciences Discuss., https://doi.org/10.5194/bg-2018-195

Manuscript under review for journal Biogeosciences

Discussion started: 3 May 2018

(C) Author(s) 2018. CC BY 4.0 License.

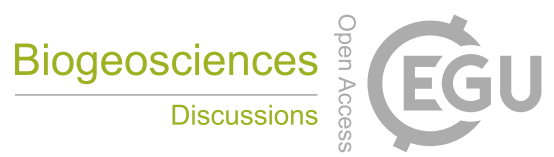

(c) (i)

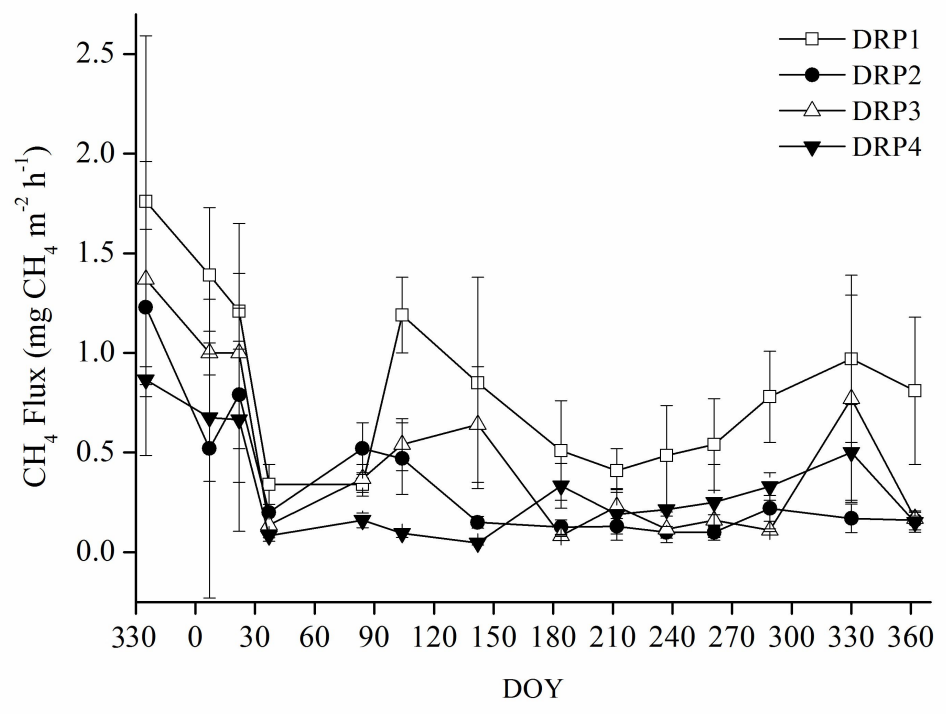

715

716

Figure 7

717 
Biogeosciences Discuss., https://doi.org/10.5194/bg-2018-195

Manuscript under review for journal Biogeosciences

Discussion started: 3 May 2018

(C) Author(s) 2018. CC BY 4.0 License.

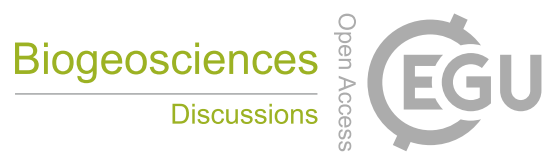

(c) (i)

718

719

720

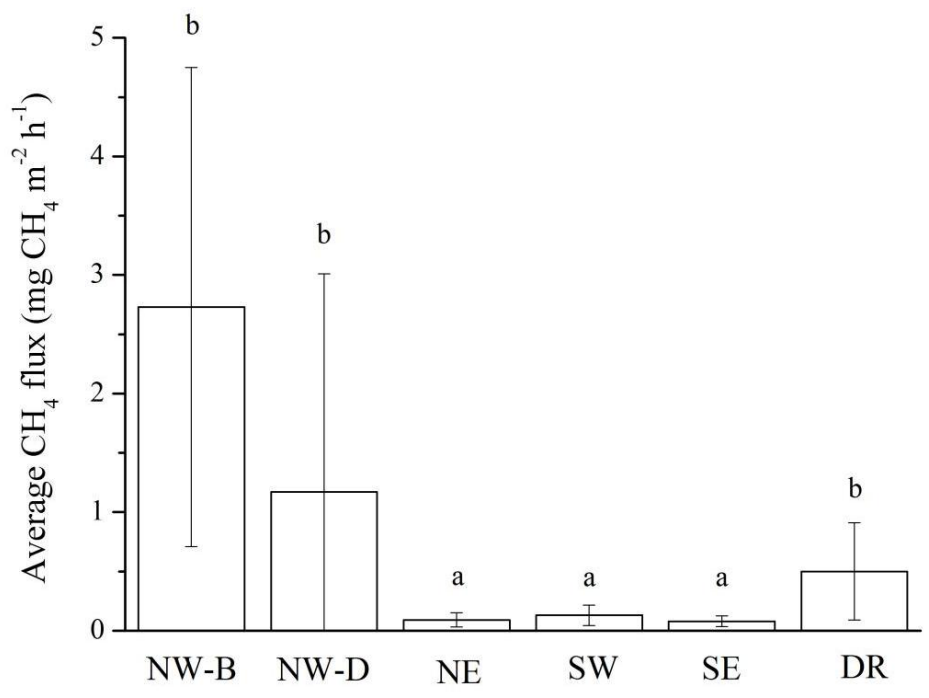

Figure 8 
Biogeosciences Discuss., https://doi.org/10.5194/bg-2018-195

Manuscript under review for journal Biogeosciences

Discussion started: 3 May 2018

(c) Author(s) 2018. CC BY 4.0 License.

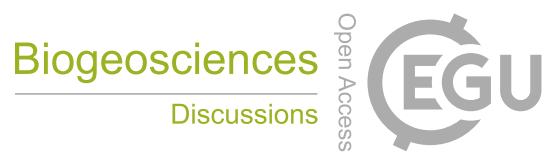

(c) (i)

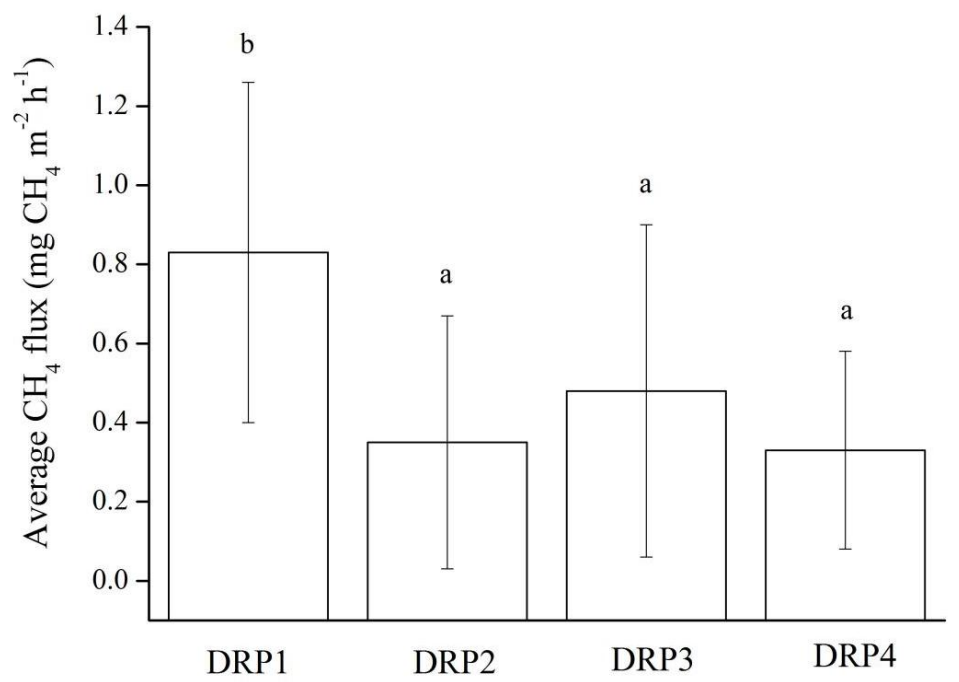

723

Figure 9 
Biogeosciences Discuss., https://doi.org/10.5194/bg-2018-195

Manuscript under review for journal Biogeosciences

Discussion started: 3 May 2018

(c) Author(s) 2018. CC BY 4.0 License.

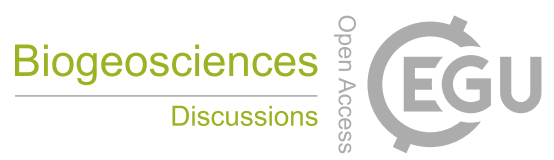

(c) (i)

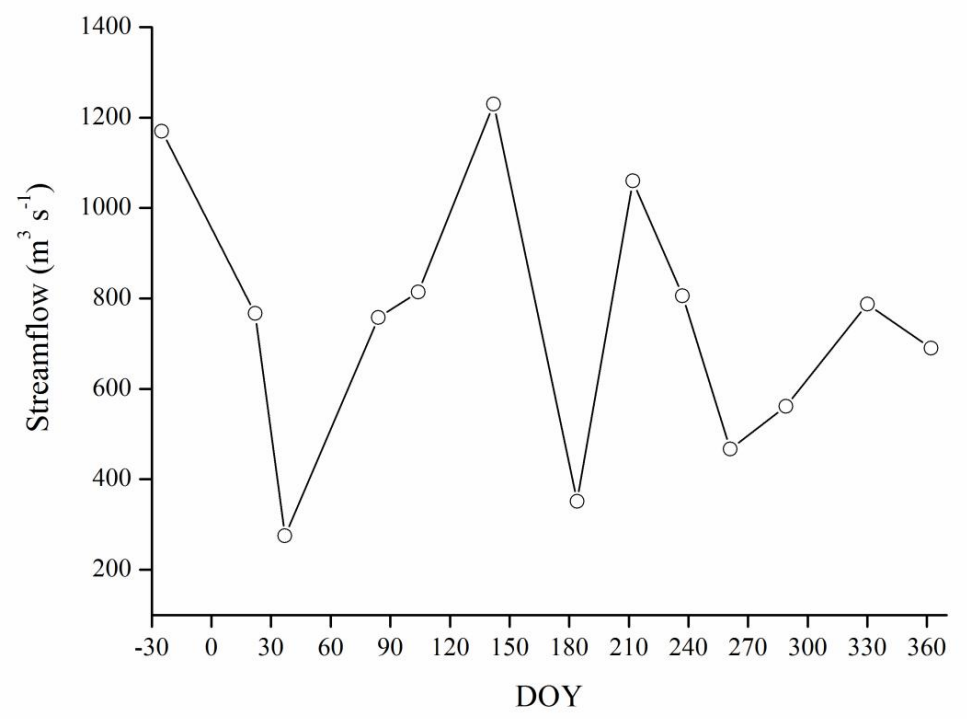

724

725

Figure 10

726 
Biogeosciences Discuss., https://doi.org/10.5194/bg-2018-195

Manuscript under review for journal Biogeosciences

Discussion started: 3 May 2018

(C) Author(s) 2018. CC BY 4.0 License.

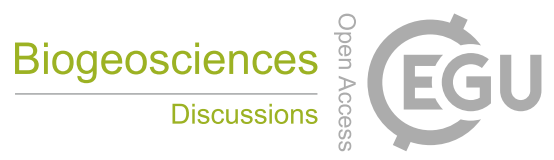

(c) (i)

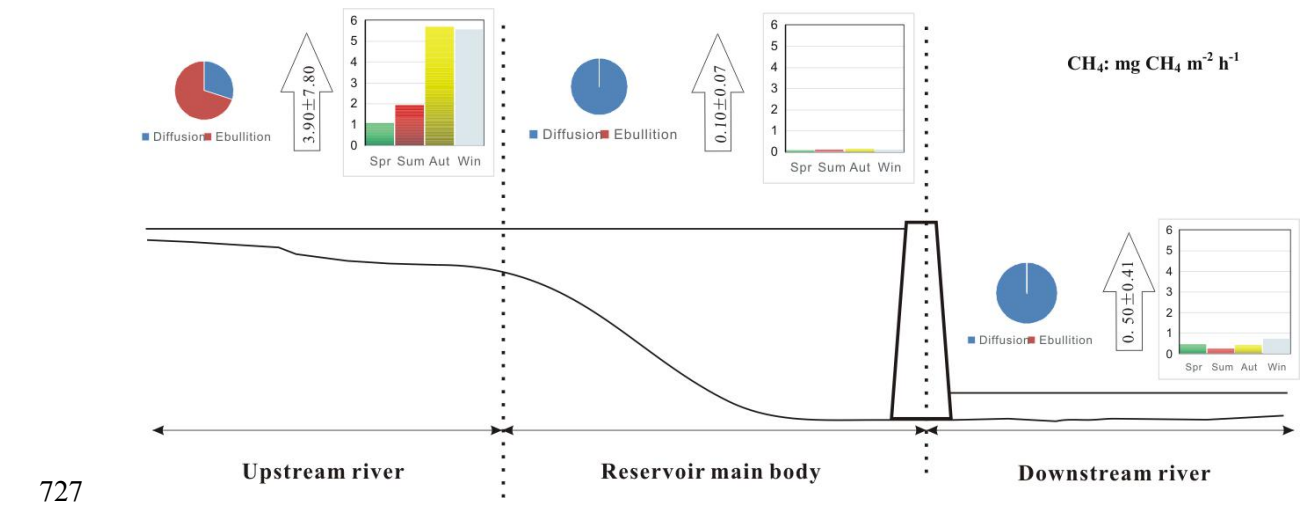

728

Figure 11

729 
Biogeosciences Discuss., https://doi.org/10.5194/bg-2018-195

Manuscript under review for journal Biogeosciences

Discussion started: 3 May 2018

(c) Author(s) 2018. CC BY 4.0 License.

Table 1. Previously reported $\mathrm{CH}_{4}$ emission from temperate and subtropical reservoirs

\begin{tabular}{|c|c|c|c|c|c|}
\hline \multirow[t]{2}{*}{ Country } & \multirow[t]{2}{*}{ Reservoir } & \multicolumn{3}{|c|}{$\mathrm{CH}_{4}$ Flux $\left(\mathrm{mg} \mathrm{CH}_{4} \mathrm{~m}^{-2} \mathrm{~h}^{-1}\right)$} & \multirow[t]{2}{*}{ Refs } \\
\hline & & Upstream river & Open water area & Downstream river & \\
\hline \multirow[t]{7}{*}{ China } & Xin'anjiang & $2.73 \pm 2.02(\mathrm{~B})$ & $0.10 \pm 0.07$ & $0.50 \pm 0.41$ & 1 \\
\hline & & $1.17 \pm 1.84(\mathrm{D})$ & & & \\
\hline & Three Gorges & $2.72 \pm 1.98$ & $0.23 \pm 0.40$ & $0.26 \pm 0.16$ & 2,3 \\
\hline & Ertan & & $0.12 \pm 0.063$ & & 4 \\
\hline & Miyun & & $0.30 \pm 0.31$ & & 5 \\
\hline & $\begin{array}{l}5 \text { small reservoirs } \\
\text { in Jiangxi Province }\end{array}$ & & $0.013 \pm 0.01$ & & 6 \\
\hline & $\begin{array}{l}16 \text { small reservoirs } \\
\text { in Chongqing }\end{array}$ & & $0.63 \pm 0.89$ & & 7 \\
\hline \multirow[t]{4}{*}{ America } & $\begin{array}{l}\text { William H. Harsha } \\
\text { Lake }\end{array}$ & $130.72 \pm 27.50$ & $9.77 \pm 2.00$ & & 8 \\
\hline & Douglas Lake & $0.018(\mathrm{D})$ & $0.017 \pm 0.012$ & & 9 \\
\hline & Eagle Creek & & $0.44 \pm 0.73$ & & 10 \\
\hline & $\begin{array}{l}\text { Six reservoirs in } \\
\text { the Western US }\end{array}$ & & $0.13-0.40$ & & 11 \\
\hline \multirow[t]{2}{*}{ Australia } & Gold Creek & $172.36 \pm 24.72$ & $12.35 \pm 6.36$ & & 12 \\
\hline & Little Nerang Dam & $247.03 \pm 254.80$ & $6.55 \pm 16.83$ & & 13 \\
\hline \multirow[t]{3}{*}{ Laos } & Nam Leuk & & $1.68 \pm 2.68$ & & 14 \\
\hline & Nam Ngum & & $0.13 \pm 0.13$ & & 14 \\
\hline & Nam Theun 2 & $0.9-2.2$ & $1.2-2.67$ & $8.0 \pm 14.7$ & $\begin{array}{l}15 \\
16\end{array}$ \\
\hline France & Eguzon & $\begin{array}{l}0.24 \pm 0.56(\mathrm{~B}) \\
2.2 \pm 3.2(\mathrm{D})\end{array}$ & $0.4(0-2.67)$ & $0.68 \pm 0.68$ & 17 \\
\hline
\end{tabular}

